\title{
Distribution of phyto- and bacterioplankton growth and biomass parameters, dissolved inorganic nutrients and free amino acids during a spring bloom in the Oosterschelde basin, The Netherlands*
}

\author{
H. J. Laanbroek** , J. C. Verplanke, P. R. M. de Visscher \& R. de Vuyst \\ Delta Institute for Hydrobiological Research, Vierstraat 28, 4401 EA Yerseke, The Netherlands
}

\begin{abstract}
Distribution of phyto- and bacterioplankton growth and biomass parameters were followed during a spring bloom in the marine Oosterschelde basin, Netherlands. Several other biotic and abiotic parameters were measured. During the measuring period from 4 April until 4 June, concentrations of the dissolved nutrients silicate, ammonium, and nitrate decreased, while dissolved phosphate tended to increase. Concentrations of chlorophyll a increased with a distinct maximum in mid May during a bloom of the haptophycean Phaeocystis pouchetii. In the shallower part of the basin maxima of particulate primary production and bacterioplankton production were reached at the end of April during a mixed bloom of diatoms of the genera Cryptomonas, Skeletonema and Thalassiosira as well as small flagellates. In the central basin, the most pronounced particulate primary production was observed during the $P$. pouchetii bloom. Relatively low percentages of extracellular release of total primary production were observed during and after this bloom. Percentage of bacterial incorporation of total exudates was high at the beginning of the experiment and decreased until the $P$. pouchetii bloom, when it increased again. Maximum bacterial productivities and biomasses were recorded during the decline of the $P$. pouchetii bloom. Overall oxygen consumption rates seemed to be determined by phytoplankton biomass and by bacterioplankton production, but not by phytoplankton production or bacterioplankton biomass. Concentrations of dissolved free amino acids (DFAA) tended to decrease until the end of the large $P$. pouchetii bloom when an increase was observed; lowest concentrations were during this bloom. Alanine, aspartate, glycine, leucine and serine were always quantitatively the most important amino acids; during the $P$. pouchetii bloom also glutamate. Mole percentages of aspartate and methionine increased at the end of this bloom.
\end{abstract}

\section{INTRODUCTION}

It is generally assumed that algae release dissolved organic matter either by excretion or by decay of senescent cells (Fogg 1983). Grazing zooplankton may increase the release of this matter from phytoplankton (Lampert 1978). Algal exudates may contribute up to $50 \%$ of the bacterioplankton energy requirements (Wiebe \& Smith 1977, Lancelot 1979, Larsson \& Hag-

\footnotetext{
- Delta lnstitute for Hydrobiological Research, Communication No. 317

- Addressee for correspondence; present address: Institute for Ecological Research, Boterhoeksestraat 22, 6666 GA Heteren, The Netherlands
}

ström 1979, Keller et al. 1982, Larsson \& Hagström 1982, Wolter 1982, Jensen 1983, Lancelot \& Billen 1984). The release of small as well as large compounds has been reported (Wiebe \& Smith 1977, Mague et al. 1980, Jørgensen et al. 1983, Lancelot 1984). In shorttime experiments, Lancelot (1984) showed that small molecules in particular were rapidly reconsumed. Dissolved free amino acids (DFAA) may form a substantial part of the small fraction (Jørgensen 1982). The amount of DFAA released in the marine environment and the contribution of the individual amino acids depend on the algal species involved (Macko \& Green 1982, Poulet et al. 1984) and on the physiological condition of the algae or the algal population (Riley \& Segar 1970, Crawford et al. 1974, Hammer \& Eberlein 1981, 
Ittekot 1982, Hammer \& Brockmann 1983, Lancelot 1983, Poulet \& Martín-Jézéquel 1983). Amino acids are submitted to rapid recycling (Laane 1983). Bacteria are well-known consumers of DFAA (Crawford et al. 1974, Dawson \& Gocke 1978, Billen et al. 1980, Sepers 1981, Amano et al. 1982, Bölter \& Dawson 1982, Jørgensen 1982, Keller et al. 1982, Hagström et al. 1984). Besides bacteria, algae may also be involved in the consumption of DFAA (Bonin \& Maestrini 1981, Admiraal et al. 1984). Thus, the production and consumption of DFAA is a dynamic process. A net in situ production of DFAA may only be demonstrable during or shortly after an algal bloom.

The aim of the present study was to determine the distribution of algal and bacterial biomass and growth parameters as well as of dissolved inorganic nutrients and free amino acids during a spring bloom. The study was carried out in the Oosterschelde basin as part of an intensive ecosystem research initiated on account of the construction of a storm surge barrier.

\section{METHODS}

Description of the area. The Oosterschelde basin in the south-westem part of the Netherlands is a former estuary still in open connection with the North Sea
(Fig. 1). Mean depth of the basin is $8 \mathrm{~m}$, of which $53 \%$ is less than $5 \mathrm{~m}$ deep, maximum depth is $55 \mathrm{~m}$ and total surface area amounts to $380 \mathrm{~km}^{2}$, of which $44 \%$ is intertidal. A hundred years ago the connection between the basin and the river Scheldt was closed by dams and since 1969 the discharge of freshwater from the rivers Rhine and Meuse is regulated by sluices. The maximum total input of freshwater amounts to $50 \mathrm{~m}^{3} \mathrm{~s}^{-1}$, whereas the mean tidal volume is approximately $1250 \times 10^{6} \mathrm{~m}^{3}$ with a mean volume of $3050 \times 10^{6} \mathrm{~m}^{3}$ for the total basin. Consequently the Oosterschelde basin is a well mixed system with a salinity of ca $27 \%$ except close to the freshwater sources.

Sampling Stations 01 and 02 (Fig. 1) were selected in the main tidal channel of the basin, both at a mean depth of $20 \mathrm{~m}$. Station 02 was surrounded by extensive intertidal mudflats.

Sample collection. During spring 1984, samples were collected weekly at half-tide around $0900 \mathrm{~h}$. Mixed samples from the euphotic zone (up to $8 \mathrm{~m}$ depth) were maintained at in situ temperature until analysis in the laboratory, which occurred always within $1 \mathrm{~h}$. Samples for amino-acid analysis were filtered immediately on board and stored at $-20{ }^{\circ} \mathrm{C}$.

Amino acid analysis. Sub-samples for DFAA analysis were gently filtered through a $0.2 \mu \mathrm{m}$ polycarbonate

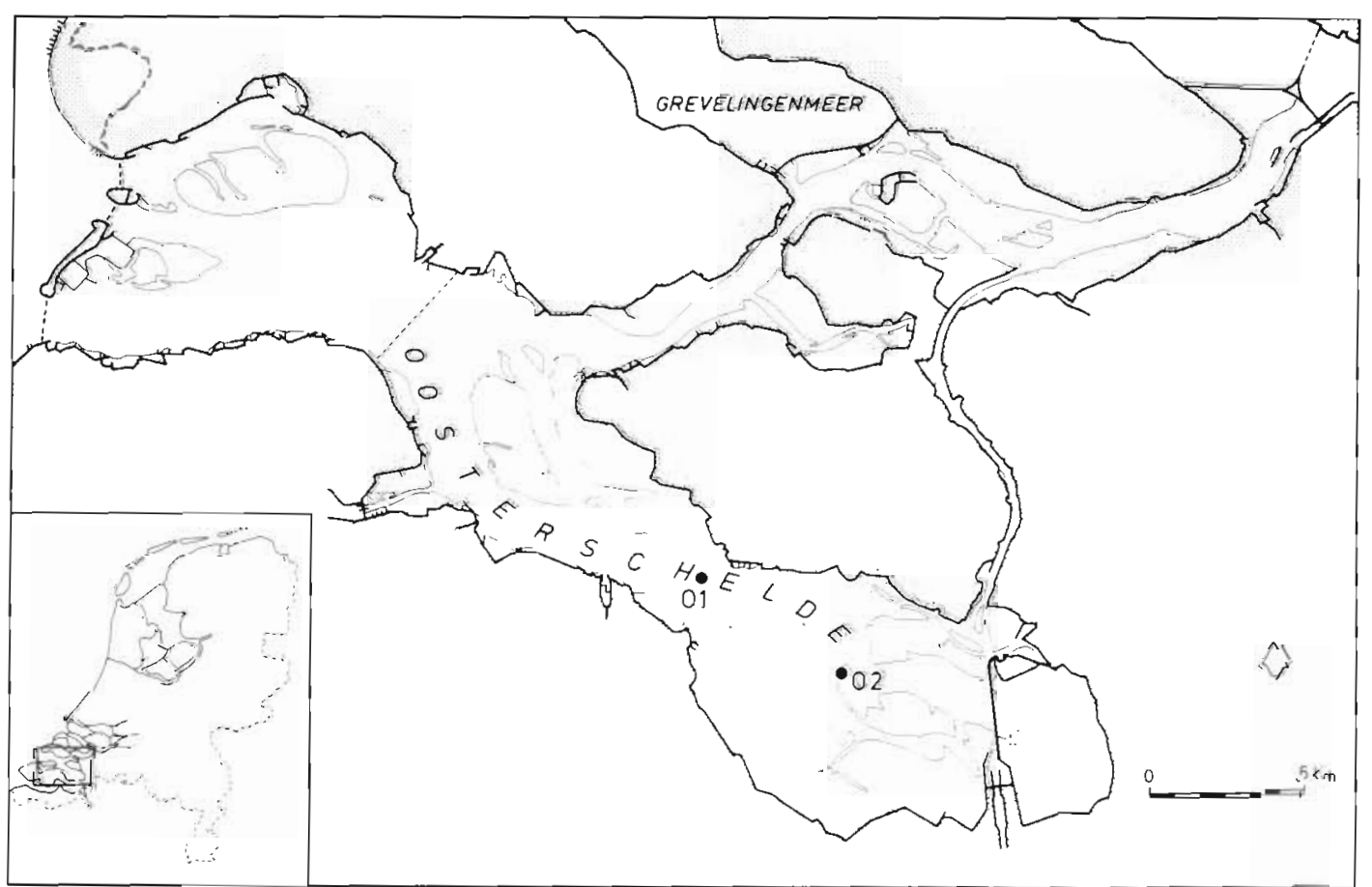

Fig. 1. Map of Oosterschelde basin in the south-western part of The Netherlands showing sampling stations; — mean level of low tide, salt-marsh edge 
filter (Nuclepore, $25 \mathrm{~mm}$ diameter) and collected in amounts of $4 \mathrm{ml}$ in ultra-cleaned vials and stored at $-20^{\circ} \mathrm{C}$. Within $3 \mathrm{wk}$, DFAA analysis was made by precolumn fluorescence derivatization with O-phthaldialdehyde using reversed-phase high performance liquid chromatography (HPLC) according to a slightly modified method of Lindroth \& Mopper (1979). Since concentrations of some amino acids appeared to decrease during storage at $-20^{\circ} \mathrm{C}$, DFAA analysis was repeated after 3 mo. Initial amino acid concentrations at time of sampling were calculated by linear extrapolation. By the method used the common amino acids, except cysteine, proline, lysine and ornithine, could be detected to levels of 1 to $10 \mathrm{nM}$ without further pretreatment of the samples. The HPLC used was Waters controlled equipment in combination with a Perkin Elmer LC-10 fluorescence detector and a $5 \mu$ resolve spherical C18 column (Waters, type P/N 85711). Amino acids were identified and quantified by spiking with standards. Depending upon the amino acid, coefficients of variation ranged from 3 to $13 \%$ for standards at the $500 \mathrm{nM}$ level.

Primary production and excretion. The classical radiocarbon method of Steeman-Nielsen (1952) was used to measure primary production. Semi situ experiments were performed in an incubator described by Fee (1973). Identical samples were illuminated at a series of irradiances from 0 to $139 \mathrm{~W} \mathrm{~m}^{-2}$. Integral daily production values were calculated from the relations between applied irradiance and measured rate of photosynthesis. Five $\mu \mathrm{Ci} \mathrm{NaH}^{14} \mathrm{CO}_{3}$ were added to 50 $\mathrm{ml}$ seawater. After 5 to $6 \mathrm{~h}$ incubation at in situ temperature, samples were gently filtered through 3.0,0.8 and $0.2 \mu \mathrm{m}$ membrane filters (Schleicher and Schull). Five $\mathrm{ml}$ of filtrate was acidified with $0.01 \mathrm{~N} \mathrm{HCl}$ to $\mathrm{pH} 2.5$ and gassed with air for $1 \mathrm{~h}$ to remove gaseous $\mathrm{CO}_{2}$. Excretion by algae with simultaneous bacterial incorporation was estimated by a slightly modified method of Wolter (1982). (Methyl- ${ }^{3} \mathrm{H}$ ) thymidine instead of ${ }^{14} \mathrm{C}$ glucose was used as tracer of bacterial size distribution. Samples of $50 \mathrm{ml}$ containing $5 \mathrm{nM}$ (methyl${ }^{3} \mathrm{H}$ ) thymidine ( $80 \mathrm{Ci} \mathrm{mmole}^{-1}$ ) were incubated at in situ temperature at an irradiance of $24 \mathrm{~W} \mathrm{~m}^{-2}$ for 5 to $6 \mathrm{~h}$, after which they were treated in the same way as the $\mathrm{NaH}^{14} \mathrm{CO}_{3}$ samples mentioned above. The irradiance of $24 \mathrm{~W} \mathrm{~m}^{-2}$ corresponds to the average irradiance in the water column of the Oosterschelde basin in spring. Since this irradiance equals approximately half the optimum irradiance for primary production in semisitu experiments, excretion by photo-inhibition could be excluded. The size fraction $<0.8 \mu \mathrm{m}$ was regarded as being free of algal primary production after correction by means of a $0.8 \mu \mathrm{m}$ prefiltered $\mathrm{NaH}^{14} \mathrm{CO}_{3}$-incubated sample. After $3 \mathrm{~h}$ incubation, the specific activity of the excreted ${ }^{14} \mathrm{C}$-labeled carbon was determined by dividing the ${ }^{14} \mathrm{C}$-labeled fraction of algal particulate material by the total phytoplankton biomass determined according to Mullin et al. (1966). Total bacterial utilization of ${ }^{14} \mathrm{C}$-labeled compounds, including the amount used for dissimilation, was calculated by assuming a bacterial carbon conversion efficiency of $75 \%$ for bacteria growing on algal exudates (Jensen 1983).

Daily solar radiation was measured at the Institute, 3 and $5 \mathrm{~km}$ from Stations 01 and 02, respectively.

Bacterial production. Bacterial production was determined with (methyl- ${ }^{3} \mathrm{H}$ ) thymidine incorporation into cold TCA-insoluble material according to the method of Fuhrman \& Azam $(1980,1982)$. Samples of $5 \mathrm{ml}$ containing $5 \mathrm{nM}$ (methyl- ${ }^{3} \mathrm{H}$ ) thymidine $(40 \mathrm{Ci}$ mmole ${ }^{-1}$, Amersham UK) were incubated in $30 \mathrm{ml}$ screw-cap bottles in the dark at in situ temperature for $3 \mathrm{~h}$. Blanks were prepared by addition of $2 \%$ formaldehyde (final concentration). The rate of thymidine incorporation into DNA was converted to bacterial production by assuming that $2.1 \times 10^{18}$ cells were produced per mole thymidine incorporated (Fuhrman \& Azam 1982). Cell production was converted to carbon production by applying the factor $1.21{\mathrm{fg} \mathrm{C} \mu \mathrm{m}^{-3}}^{-3}$ (Watson et al. 1977).

Oxygen consumption rates. As an index of overall heterotrophic activity, bacterial as well as algal, oxygen consumption rates were determined. Ten oxygen bottles were filled with water, 5 bottles immediately fixed and 5 incubated in the dark at in situ temperature for $24 \mathrm{~h}$ and then fixed. Oxygen concentrations were determined by Winkler titration according to Bryan et al. (1976).

Biomass estimates. Chlorophyll a concentrations were used as an index of phytoplankton biomass. Samples for chlorophyll a analysis were obtained by filtration of water samples over fiber-glass filters (Schleicher and Schull No. 6). Chlorophyll a analysis was by high performance liquid chromatography using a slightly modified method of Gieskes \& Kraay (1983). The method was calibrated by using standards of pure chlorophyll a (Sigma), the concentration of which was determined spectrophotometrically (Lorenzen 1966).

Direct counts of bacteria and simultaneous determinations of mean cell volumes were performed on black stained $0.2 \mu \mathrm{m}$ polycarbonate filters using the fluorescent dye acridine orange (Hobbie et al. 1977). Bacterial cell-carbon was obtained from the bacterial number and mean cell volume by applying the conversion factor of $1.21 \mathrm{fg} \mathrm{C} \mathrm{mm}^{-3}$ (Watson et al. 1977).

Chemical analyses. Ortho-phosphate, reactive silicate, ammonium-nitrogen and nitrate-nitrogen were measured on a Technicon AA II auto-analyser, according to slightly modified techniques described by Strickland \& Parsons (1972). 


\section{RESULTS AND DISCUSSION}

\section{Dissolved inorganic nutrients}

A period with steady weather and a relatively high level of daily solar radiation (average $8.36 \times 10^{6} \mathrm{~J} \mathrm{~m}^{-2}$, Fig. 2a) during the last weeks of April caused a rapid increase of water temperature from 6 to $12^{\circ} \mathrm{C}$. (Fig. 2b).
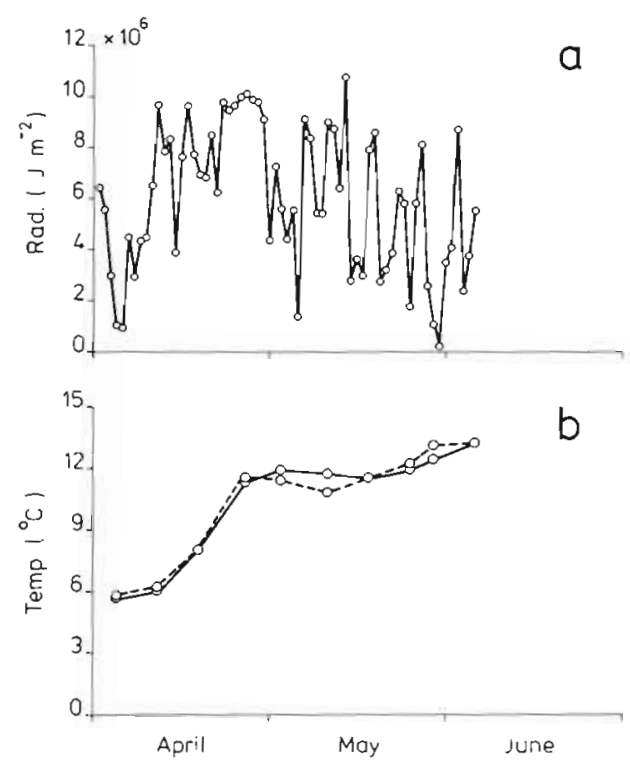

Fig. 2. Distribution of (a) solar radiation and (b) water temperature at Station $01(-)$ and Station $02(--)^{-}$

From the beginning of May the weather became less steady, average daily solar radiation decreased to $5.24 \times 10^{6} \mathrm{~J} \mathrm{~m}^{-2}$, and the increase of water temperature was subsequently less pronounced. There was no consistent difference between the 2 sampling stations.

Concentrations of nutrients measured at both stations differed only slightly. Concentrations of dissolved phosphate tended to increase at both stations (Fig. 3a). A distinct minimum was observed during a bloom of the haptophyceae Phaeocystis pouchetij in the middle of May (Table 1). A low concentration of dissolved phosphate in spring followed by an increase in June was also observed in the saline Lake Grevelingen, a former estuary in the direct vicinity of the Oosterschelde basin (Fig. 1) (Lindeboom \& Merks 1983). In Lake Grevelingen, the increase in concentration of dissolved phosphate was not dependent on water temperature, but seemed to be a result of changing conditions in the sediments. Unlike dissolved phosphate, silicate concentration in the water decreased rapidly during the last weeks of April. At this time diatoms of the genera Skeletonema and Thalassiosira were quantitatively important in the Oosterschelde basin (Table 1). The concentration of silicate remained

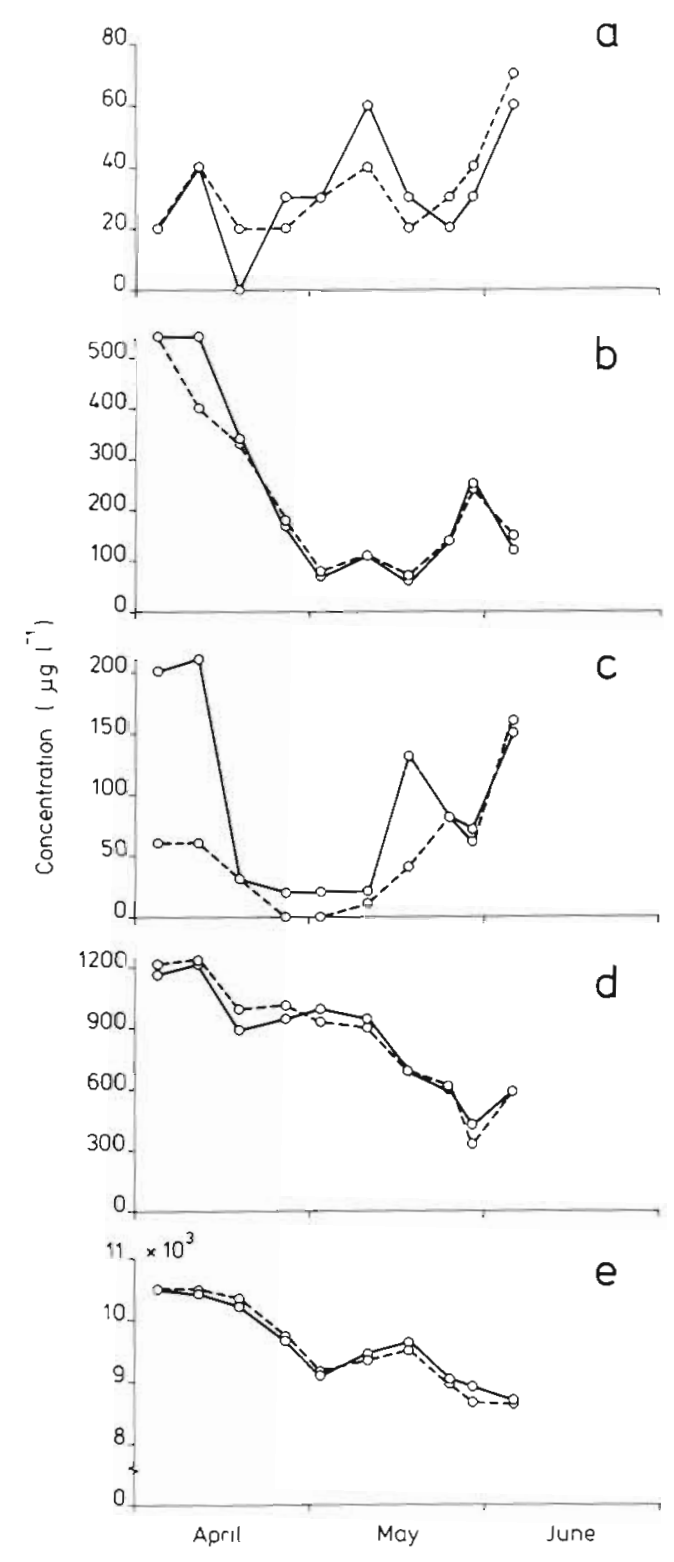

Fig. 3. Distribution of abiotic parameters $\left(\mu \mathrm{gl}^{-1}\right)$ in the water column of the Oosterschelde basin in spring 1984 at Station 01 (- - ) and Station 02 (- - -). (a) dissolved phosphate; (b) reactive silicate; (c) ammonium-nitrogen; (d) nitrate-nitrogen; (e) dissolved oxygen

at a low level in May until the end of the $P$. pouchetii bloom when a temporary increase of silicate was observed at both stations (Fig. 3b). Apparently, $P$. pouchetii had been outcompeting diatoms for nutrients leaving dissolved silicate in the water column of the basin. The concentration of dissolved ammonium in the water also decreased rapidly during the last weeks of April (Fig. 3c), probably through the activity of primary producers. At the end of the measuring period, the amount of dissolved ammonium increased again, possibly through the activity of heterotrophic, 
Table 1. Dominant phytoplankton species enumerated at Station 02 in spring 1984; cell numbers $\mathrm{ml}^{-1}$ (C. Bakker \& J. C. M. Weststrate-Rijk unpubl. results)

\begin{tabular}{|c|c|c|c|c|c|c|c|c|c|}
\hline \multirow[t]{2}{*}{ Species } & \multicolumn{9}{|c|}{ Sampling date } \\
\hline & $4 \mathrm{Apr}$ & $11 \mathrm{Apr}$ & $18 \mathrm{Apr}$ & $26 \mathrm{Apr}$ & 2 May & 10 May & 17 May & 24 May & 4 Jun \\
\hline Biddulphia aurita & 4 & 1 & 11 & nd & nd & nd & nd & nd & nd \\
\hline Cryptomonas spp. (large) & 263 & 340 & 312 & 732 & 508 & 599 & 286 & 496 & 315 \\
\hline Cryptomonas spp. (small) & 68 & 185 & 99 & 794 & 1379 & 678 & 284 & 75 & 416 \\
\hline Flagellates $(0$ to $4 \mu \mathrm{m}\}$ & 154 & 385 & 554 & 933 & 675 & 251 & 140 & nd & 339 \\
\hline Phaeocystis pouchetii & nd & nd & nd & nd & 54 & 2603 & 14842 & 2174 & nd \\
\hline Rhizosolenia spp. & nd & nd & nd & nd & 10 & nd & 5 & nd & 52 \\
\hline Skeletonema costatum & 227 & 178 & 1158 & 1253 & 396 & 238 & 81 & 97 & 70 \\
\hline Thalassiosira spp. & 99 & 39 & 130 & 130 & 33 & 16 & 8 & 7 & 5 \\
\hline
\end{tabular}

ammonifying bacteria (Sepers 1981). The concentration of dissolved nitrate decreased steadily during the period of study (Fig. 3d). Relatively large decreases were observed in the middle of April when the concentrations of dissolved ammonium and silicate also decreased rapidly, and during the second half of May, a period characterized by the large $P$. pouchetii bloom. The concentration of oxygen decreased slowly during the period of study (Fig. 3e). However, a small increase in oxygen concentration was observed during the first half of May at the time of the $P$, pouchetii bloom. The water was always slightly oversaturated with oxygen, but saturation tended to decrease towards the end of the measuring period.

\section{Phytoplankton biomass, particulate production and excretion}

The concentration of chlorophyll a determined by HPLC was taken as an index of phytoplankton biomass. Dynamics in phytoplankton developments in coastal waters could approximately be followed by measurements of chlorophyll a (Côté \& Platt 1983). However it should be kept in mind that no quantitative aspects of total phytoplankton carbon biomass could be extracted from such measurements, since carbon to chlorophyll a ratios are dependent on temperature and light conditions (Bienfang et al. 1983, Redalje 1983, Redalje \& Laws 1983), on nutrient limitations (Laws \& Bannister 1980) and on algal species involved (Perry et al. 1981). All these biotic and abiotic conditions changed throughout the period of study. A moderate increase in chlorophyll a concentration was observed up to mid May at both stations (Fig. 4a). A mixed bloom of diatoms and small flagellates at Station 02 in the second half of April (Table 1) was not reflected in the concentrations of chlorophyll a determined by HPLC.
On May 17 a large increase in chlorophyll a concentration was observed at both stations. The increase was most pronounced at Station 01. Within a week the chlorophyll a concentrations decreased again to levels measured before the bloom. Particulate phytoplankton production increased from the beginning of observations at both stations (Fig. 4b). However, while particulate primary production reached a more or less stable level in the middle of April at Station 01, particulate production at Station 02 continued to increase for another week and reached a relatively high value, after which it declined again to a level comparable to values measured at Station 01. At Station 02, maximum numbers of Cryptomonas, Skeletonema and Thalassiosira species as well as small flagellates were observed at the end of April (Table 1). The observed maximum in phytoplankton particulate production on April 26 at Station 02 coincided with a temporary maximum in bacterioplankton production at the same date and at the same station (Fig. 4e). At Station 01, such a maximum in bacterioplankton production was not observed. A second increase in particulate primary production was observed at May 17 at both stations during the bloom of Phaeocystis pouchetii in colonial stage (Table 1). At that time the maxima in particulate production coincided with maxima in chlorophyll a concentrations. After May 17 both phytoplankton biomass and particulate production declined again to lower levels.

Phytoplankton extracellular release and a concomitant incorporation by bacterioplankton was determined in samples taken at Station 01. Total excretion rates were relatively high in April before and during a mixed bloom of diatoms and small flagellates, but low during the $P$. pouchetii bloom in the middle of May (Fig. 3c). Since excretion rates were determined only at one irradiance $\left(24 \mathrm{~W} \mathrm{~m}^{-2}\right)$ we consider it inappropriate to use these rates for calculations of daily excretion 

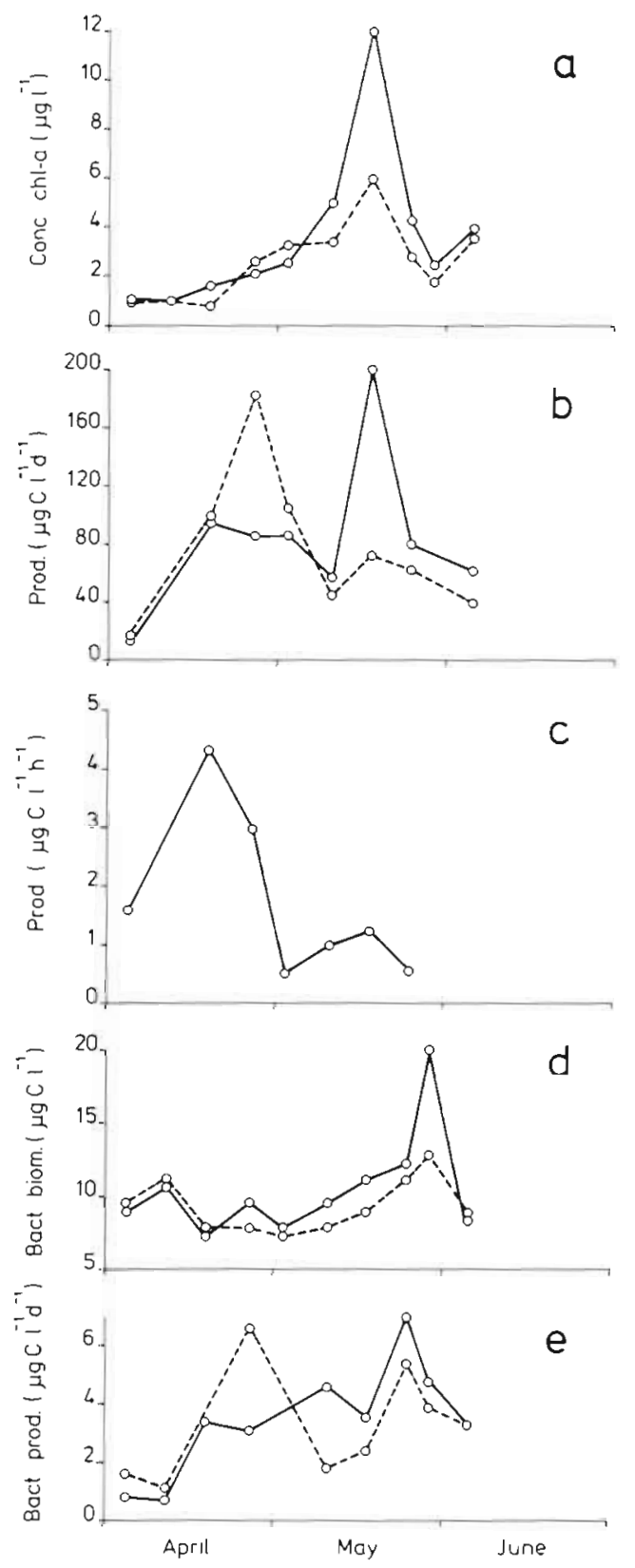

Fig. 4. Distribution of biotic parameters in the water column of the Oosterschelde basin in spring 1984 at Station $01(-)$ and Station $02(-\cdots)$. (a) chlorophyll a concentration $\left(\mu \mathrm{g} \mathrm{l}^{-1}\right)$; (b) particulate primary production rate $\left(\mu \mathrm{gC} \mathrm{l}^{-1} \mathrm{~d}^{-1}\right)_{i}$ (c) rate of algal extracellular release $\left(\mu \mathrm{CC}^{-1} \mathrm{~h}^{-1}\right)$; (d) bacterioplankton biomass ( $\mu \mathrm{gC}^{-1}$ ); (e) bacterioplankton production rates ( $\mu \mathrm{gC}$ $\left.\mathrm{l}^{-1} \mathrm{~d}^{-1}\right)$

rates as was done in the case of particulate primary production. So, excretion rates were only compared with production rates determined at the same irradiance. No correlation was found between extracellular release and particulate primary production. The percentage extracellular release (PER) was high during the mixed bloom in April and low during the mid-May $P$. pouchetii bloom (Table 2). As in the Kiel Fjord (Wolter 1982), PER values were apparently dependent upon the dominant phytoplankton species in the Oosterschelde basin. With respect to the $P$. pouchetii bloom, our results are contradictory to the observations of Lancelot (1983). PER values as high as $80 \%$ were recorded by her during the decline of a bloom of $P$. pouchetii in the southern bight of the North Sea. A bacterioplankton carbon conversion coefficient for algal exudates of $75 \%$ (Jensen 1983) was assumed for calculation of PER values in the Oosterscheide basin. These PER values would increase when assuming a bacterial carbon conversion efficiency less than $75 \%$. Lancelot \& Billen (1984) calculated a conversion coefficient of 10 to $30 \%$ during a $P$. pouchetii bloom. Bacterial carbon conversion efficiencies as low as $10 \%$ have also been recorded by Newell et al. (1981), but these values concerned the bacterial incorporation of phytoplankton cell debris, which are more refractory than labile compounds released by living phytoplankton. PER values as low as $5 \%$ were also determined by Veldhuis \& Colijn (pers. comm.) during a bloom of $P$. pouchetii. So, correct PER values during blooms of $P$. pouchetii are still obscure.

Percentages of bacterioplankton utilization of total exudates fluctuated during the measuring period (Table 2). High percentages of bacterial utilization of total exudates were found in early April when the total amounts of excreted organic carbon were also relatively high. The percentages of bacterial utilization of total exudates decreased when primary production increased. An increase in the percentage of bacterial utilization of total exudates was observed during the decline of the Phaeocystis pouchetii bloom.

Relatively high percentages of total bacterioplankton activities, as determined by (methyl- ${ }^{3} \mathrm{H}$ ) thymidine incorporation during semi-situ incubation, were retained by $3 \mu \mathrm{m}$ membrane filters (Table 3 ). The percentage of total activity retained by the $3 \mu \mathrm{m}$ membrane increased during the experimental period. A possible explanation for this phenomenon could be found in an increase of the percentage bacteria attached to larger particles. However, rather the opposite was observed. The percentage of epibacteria decreased during the experimental period at both stations. So, once again the inefficiency of membrane filters for separation of suspended matter has been shown (Hobbie et al. 1977, Danielsson 1982).

\section{Bacterioplankton biomass and production}

Bacterioplankton biomass was fairly constant at both stations until the end of the Phaeocystis pouchetii bloom at the end of May when maxima in bacterio- 
Table 2. Percentages of algal extracellular release of total primary production, and of bacterial utilization of total exudates, both determined with $\mathrm{NaH}^{14} \mathrm{CO}_{3}$ during 5 to $6 \mathrm{~h}$ incubation experiments at $24 \mathrm{~W} \mathrm{~m} \mathrm{~m}^{-2}$ and in situ temperature

\begin{tabular}{|c|c|c|c|c|c|c|c|c|}
\hline & \multicolumn{8}{|c|}{ Sampling date } \\
\hline & $4 \mathrm{Apr}$ & $18 \mathrm{Apr}$ & $26 \mathrm{Apr}$ & 2 May & $10 \mathrm{May}$ & 17 May & 24 May & 4 Jun \\
\hline Extracellular release & $24 \%$ & $23 \%$ & $26 \%$ & $5 \%$ & $6 \%$ & $2 \%$ & $3 \%$ & nd \\
\hline Bacterial utilization & $93 \%$ & $85 \%$ & $82 \%$ & $40 \%$ & $6 \%$ & $36 \%$ & $58 \%$ & $50 \%$ \\
\hline
\end{tabular}

Table 3. Size distribution of bacterial activity as determined by incorporation of (methyl- ${ }^{3} \mathrm{H}$ )thymidine during 5 to $6 \mathrm{~h}$ incubation at $24 \mathrm{~W} \mathrm{~m}^{-2}$ and in situ temperature

\begin{tabular}{|cccc|}
\hline $\begin{array}{c}\text { Sampling } \\
\text { date }\end{array}$ & \multicolumn{3}{c|}{$\begin{array}{c}\text { Percent total bacterial activity } \\
\text { at following pore sizes }\end{array}$} \\
& $0.2 \mu \mathrm{m}$ & $0.8 \mu \mathrm{m}$ & $3.0 \mu \mathrm{m}$ \\
\hline 4 Apr & 24 & 35 & 41 \\
$18 \mathrm{Apr}$ & 21 & 46 & 33 \\
$26 \mathrm{Apr}$ & 16 & 59 & 25 \\
$2 \mathrm{May}$ & 26 & 39 & 35 \\
$10 \mathrm{May}$ & 25 & 33 & 42 \\
17 May & 14 & 23 & 63 \\
24 May & 21 & 13 & 66 \\
4 Jun & 21 & 14 & 65 \\
\hline
\end{tabular}

plankton biomass were observed (Fig. 4 d). These maxima in biomass were preceeded by maxima in bacterioplankton carbon production (Fig. 4e). For the whole measuring period, bacterioplankton biomass and production were not significantly correlated, neither were these bacterioplankton parameters significantly correlated with the corresponding phytoplankton parameters. However, from the middle of May a distinct succession of events could be observed in the water column (Fig. 4). The bloom of $P$. pouchetii with high production levels but low PER values was followed by an increase of bacterioplankton production, which gave rise to bacterioplankton biomass maxima. Such a time-lag between phyto- and bacterioplankton parameters after a bloom of $P$. pouchetii was also observed in the coastal zone of the southern North Sea by Lancelot \& Billen (1984). A high production level of bacterioplankton with a corresponding high production level of particulate primary production was observed at April 26 at Station 02. Incorporation of (methyl- ${ }^{3} \mathrm{H}$ ) thymidine into phytoplankton DNA can be excluded (Findlay et al. 1984, Pollard \& Moriarty 1984). The rates of (methyl- ${ }^{3} \mathrm{H}$ ) thymidine incorporation measured in the Oosterschelde basin (2.3 to 22.9 pMole $\mathrm{l}^{-1} \mathrm{~h}^{-1}$ ) were within the range of incorporation rates measured in the coastal zone of the southern North Sea by Lancelot \& Billen (1984). The bacterial carbon pro- duction rates also agreed well with production rates found in other coastal zones (see Ducklow 1983).

However, if the bacterioplankton production rates measured in the Oosterschelde basin are correct and a bacterioplankton carbon conversion coefficient of $75 \%$ is assumed for phytoplankton exudates, only a minor part (average $5 \%$ ) of the primary production could simultaneously be utilized by the bacterioplankton. In the Baltic Sea, approximately $15 \%$ of primary production is used by bacterioplankton (Larsson \& Hagström 1982, Wolter 1982). In the Belgian coastal zone, direct substrate utilization by heterotrophic bacteria amounted to 44 to $68 \%$ of total primary production (Lancelot \& Billen 1984). The rate of bacterioplankton production in the Oosterschelde basin as determined by the incorporation of (methyl- ${ }^{3} \mathrm{H}$ )thymidine is also low compared to the rate of bacterioplankton utilization of phytoplankton exudates as can be calculated from Fig. $4 \mathrm{c}$ and Table 2 . This means that the amount of algal extracellular release was possibly overestimated by underestimating the specific activity of released organic compounds. This is not entirely unlikely, since released metabolic compounds may have been labeled at a higher rate than more structural compounds used to determine specific activity. On the other hand, incorporation of (methyl- ${ }^{3} \mathrm{H}$ )thymidine may have underestimated the actual bacterioplankton production rates due to the non-equilibrium of the specific activity of the nucleotide (Moriarty \& Pollard 1981, 1982, Riemann \& Søndergaard 1984).

\section{Overall oxygen consumption}

Overall oxygen consumption rates were measured to determine total heterotrophic activity including dark respiration by phytoplankton (Straskrabova 1979). Two maxima in overall oxygen consumption rates could be distinguished (Fig. 5), one on April 26 and one around May 17 both at times of maximum phytoplankton numbers (Table 1). Overall oxygen consumption rates were well correlated with water temperature, chlorophyll a concentrations and bacterioplankton production rates. 


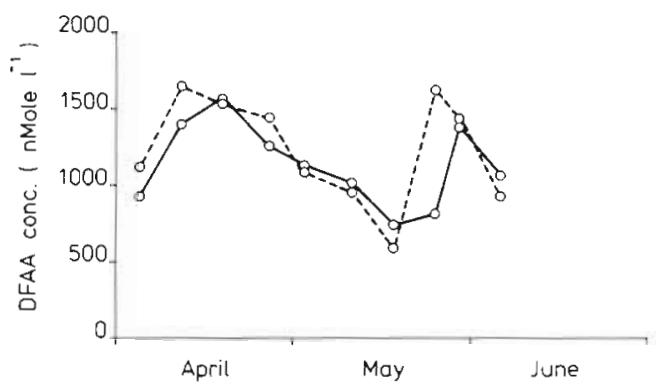

Fig. 5. Distribution of total oxygen uptake rates $\left(\mu \mathrm{g}^{-1} \mathrm{~d}^{-1}\right)$ in water samples taken at Station 01 (-) and Station $\left.02(-)^{-}\right)$in the Oosterschelde basin in spring 1984

No significant correlation was found between overall oxygen consumption rates on the one hand and the particulate phytoplankton production rates and the bacterioplankton biomasses on the other hand. So, overall oxygen consumption rates were apparently determined by phytoplankton biomass and not by phytoplankton production, whereas the opposite was found for bacterioplankton parameters. Bacterioplankton production and not biomass determined overall oxygen consumption rates.

According to size fractionation experiments, approximately $50 \%$ of total pelagic oxygen consumption rates could be attributed to bacterioplankton activity in the Oosterschelde basin in spring (Laanbroek et al. unpubl.). Assuming a carbon:oxygen ratio of 0.29 (Sepers 1981) as well as a bacterioplankton carbon conversion coefficient of $75 \%$, bacterioplankton production rates varied between 52 and $357 \mu \mathrm{g} \mathrm{Cl}^{-1} \mathrm{~d}^{-1}$ during the measuring period. These values are of the same magnitude as the values found for particulate primary production (Fig. $4 \mathrm{~b}$ ). However, the carbon conversion coefficient of $75 \%$ used for exudates may be too high for other organic compounds used by the bacterioplankton as was discussed above. A conversion coefficient of $10 \%$ would yield bacterioplankton production rates between 2 and $13 \mathrm{~kg} \mathrm{Cl}^{-1} \mathrm{~d}^{-1}$, which is of the same magnitude as the bacterioplankton production rates as determined with (methyl ${ }^{3} \mathrm{H}$ ) thymidine incorporation.

\section{Distribution of dissolved free amino acids}

A temporary increase in DFAA was observed in the beginning of April at both stations (Fig. 6), which agreed well with the initial production of algal extracellular organic compounds (Fig. 4c). From April 11 on, the concentration of DFAA decreased steadily until the end of the Phaeocystis pouchetii bloom (Fig. $4 \mathrm{~b}$, Table 1). Minimum amounts of DFAA were found during this bloom. Increases in the concentration of DFAA were observed at the end of this bloom. These increases in DFAA corresponded with increases in

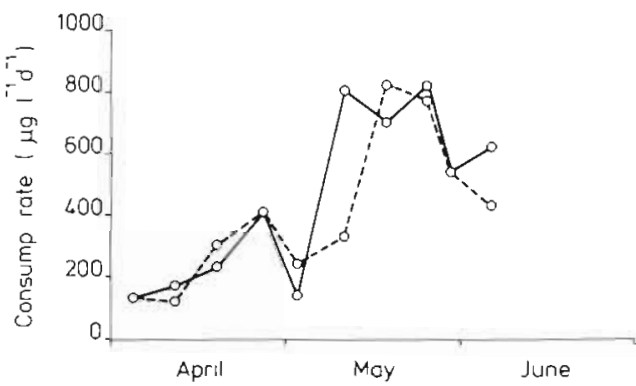

Fig. 6. Distribution of dissolved free amino acids (nMole $\mathrm{l}^{-1}$ ) in water samples taken at Station 01 (-) and Station $02(--)$ in the Oosterschelde basin in spring 1984

bacterioplankton biomass (Fig. 4d) and bacterioplankton production (Fig. 4e). The difference of some days between the times of observed maximum concentrations of DFAA at both stations may be a result of the sampling frequency. The real maxima in the water column may have been missed by this sampling frequency. But there may also have been some effect of the intertidal mudflats around Station 02 on the distribution of DFAA. Release from the sediment surface appeared to be the major source of DFAA in the water of a shallow Danish fjord (Jørgensen 1982) and the presence of a possible aspartic acid-hydroxyproline dimer gave some evidence of sediment resuspension at a deeper water-layer of Chesapeake Bay (Sigleo et al. 1983). However, no influence of intertidal mudflats on the distribution of individual amino acids at Station 02 was observed. No quantitatively important differences were observed between stations. The in situ amino acid concentrations were slightly high compared to those measured in coastal waters elsewhere (Dawson \& Gocke 1978, Billen et al. 1980, Keller et al. 1982, Mopper \& Lindroth 1982, Poulet et al. 1984). Concentrations comparable to those detected in the Oosterschelde basin were found by Jørgensen (1982) in spring and autumn in a shallow estuary on the coast of Denmark.

The percentage distribution of DFAA observed at Station 01 is summarized in Fig. 7. During most of the measuring period, the distribution of individual amino acids was fairly constant. Alanine, aspartate, glycine, leucine and serine were always quantitatively the most important amino acids. These amino acids constituted at least $60 \%$ of total DFAA. The predominance of these amino acids, sometimes together with ornithine and lysine, is a commonly observed phenomenon in marine or estuarine waters (Bohling 1970, Dawson \& Gocke 1978, Billen et al. 1980, Amano et al. 1982, Jørgensen 1982, Keller et al. 1982, Macko \& Green 1982, Mopper \& Lindroth 1982, Sigleo et al. 1983, Poulet et al. 1984). Unfortunately, ornithine and lysine were not detected by our HPLC procedure. These more or less fixed patterns of individual amino acids 


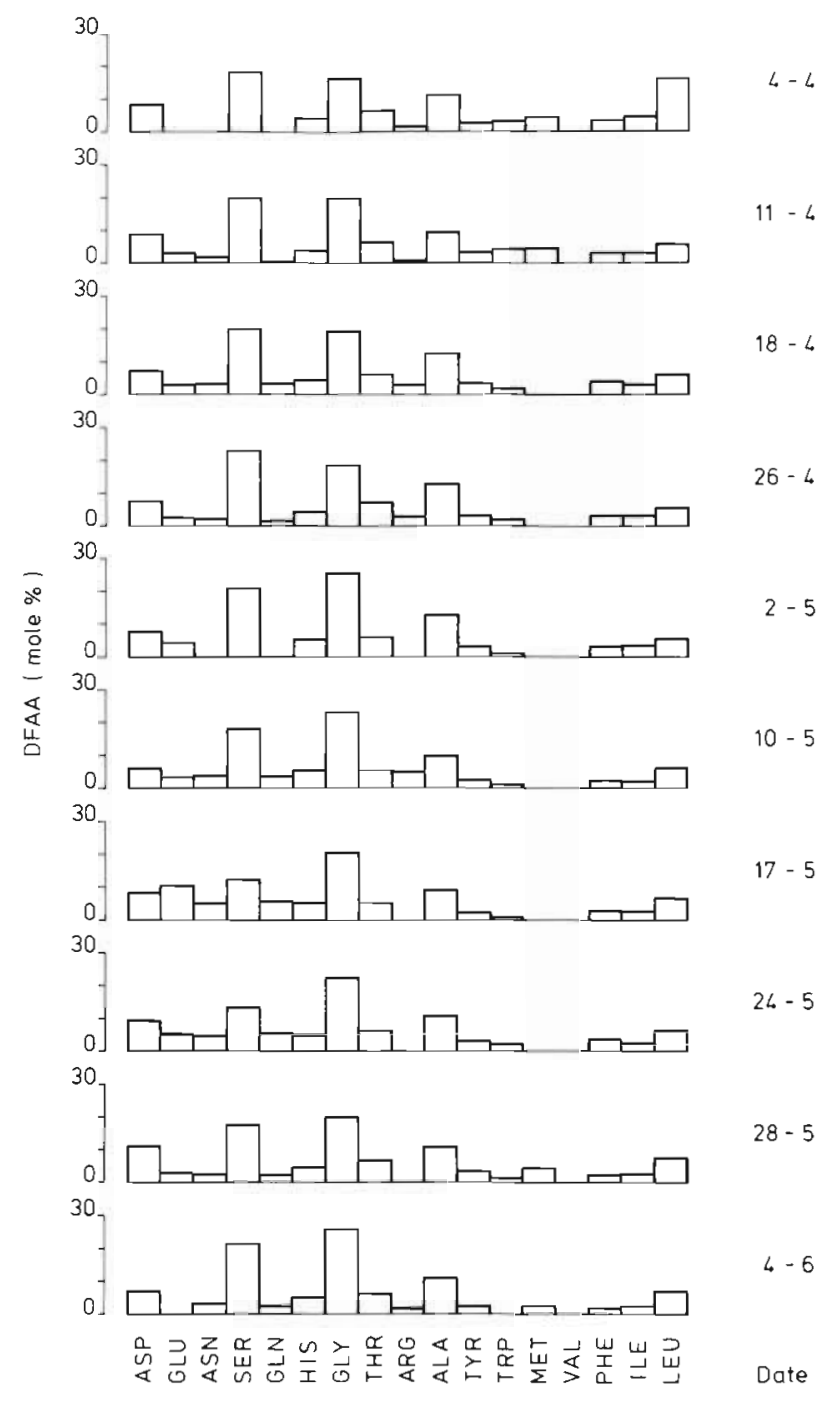

Fig. 7. Percentage distribution of individual dissolved free amino acids in water samples taken at Station 01

encountered in many marine and estuarine water bodies suggest a fixed pattern of amino acids released by different phytoplankton species or suppose the presence of an adequate population of heterotrophic bacteria consuming released DFAA. Maximum mole percentages of aspartine, glutamine and especially of glutamate were measured at the peak of the Phaeocystis pouchetii bloom (Fig. 7). On the other hand maximum mole percentages of aspartate and methionine were observed after this bloom. Although gentle filtration was applied for DFAA analysis, a part of the measured amino acids may have been originated from mucilaginous compounds of the $P$. pouchetii colonies. These DFAA were indistinguishable from excreted amino acids in our experiments.

Different behaviour in distribution of individual amino acids in relation to algal blooms has been observed before. Seasonal variations in DFAA were observed in coastal waters by Bohling (1970) and Riley $\&$ Segar (1970). In the northern North Sea, a glutamate maximum was also registered in the early stages of a Chaetoceros bloom, whereas histidine was found in maximum concentrations towards the end of the bloom (Ittekot 1982). Macko \& Green (1982) mentioned highly significant correlations between glutamate and lysine on the one hand and blooms of Asterionella and Chaetoceros on the other hand in the Damariscotta River estuary. However, as in our experiments, the presence of a selective population of bacteria as well as zooplankton could not be excluded from the data in literature. And finally, it should be kept in mind that the amounts of chemically detectable DFAA may not necessarily be identical to biologically significant amino acids (Dawson \& Gocke 1978).

Acknowledgements. This research was partly supported by the Delta Service of the Dutch Ministry of Public Works. We are grateful to the crew of M. S. 'Jan Verwey' for bringing us safely to the sampling stations, to Mr. J. O. van der Zande for doing the nutrient analyses, and to Mr. A. A. Bolsius for drawing the figures. We thank Drs. W. Admiraal, F. Colijn and $\mathrm{S}$. A. de Jong for valuable discussions.

\section{LITERATURE CITED}

Admiraal, W., Laane, R. W. P. M., Peletier, H. (1984). Participation of diatoms in the amino acid cycle of coastal waters; uptake and excretion in cultures. Mar. Ecol. Prog. Ser. 15: 303-306

Amano, M., Hara, S., Taga, N. (1982). Utilization of dissolved amino acids in seawater by marine bacteria. Mar. Biol. 68: $31-36$

Bienfang, P., Szyper, J., Laws, E. (1983). Sinking rate and pigment responses to light-limitation of a marine diatom: implications to dynamics of chlorophyll maximum layers. Oceanologica Acta 6: 55-62

Billen, G., Joiris, C., Wijnant, J., Gillain, G. (1980), Concentration and microbiological utilization of small organic molecules in the Scheldt estuary, the Belgian coastal zone of the North Sea and the English Channel. Estuar. coast. mar. Sci. 11: 279-294

Bohling, H. (1970). Untersuchungen über frei gelöste Aminosäuren in Meerwasser. Mar. Biol. 6: 213-225

Bölter, M., Dawson, R. (1982). Heterotrophic utilisation of biochemical compounds in antartic waters. Neth. J. Sea Res. 16: 315-332

Bonin, D. J., Maestrini, S. Y. (1981). Importance of organic nutrients for phytoplankton growth in natural environments, implications for algal succession. In: Platt, T. (ed.) Physiological basis of phytoplankton ecology. Can. Bull. Fish. Aquat. Sci. 210: 279-291

Bryan, J. R., Riley, J. P., Williams, P. J. LeB. (1976). A Winkler procedure for making precise measurements of oxygen concentration for productivity and related studies. J. exp. mar. Biol. Ecol. 21: 191-197

Côté, B., Platt, T. (1983). Day-to-day variations in the springsummer photosynthetic parameters of coastal marine phytoplankton. Limnol. Oceanogr. 28: 320-344 
Crawford, C. C., Hobbie, J. E., Webb, K. L. (1974). The utilization of dissolved free amino acids by estuarine microorganisms. Ecology 55: 551-563

Danielsson, L. G. (1982). On the use of filters for distinguishing between dissolved and particulate fraction in natural waters. Water Res. 16: 179-182

Dawson, R., Gocke, K. (1978). Heterotrophic activity in comparison to the free amino acid concentrations in Baltic sea water samples. Oceanologica Acta 1: 45-54

Ducklow, H. W. (1983). Production and fate of bacteria in the ocean. Bioscience 33: 494-501

Fee, E. J. (1973). A numerical model for determining integral primary production and its application to lake Michigan. J. Fish. Res. Bd Canada 30: 1447-1468

Findlay, S. E. G., Meyer, J. L., Edwards, R. T. (1984). Measuring bacterial production via rate of incorporation of $\left({ }^{3} \mathrm{H}\right)$ thymidine into DNA. J. microbiol. Meth. 2: 57-72

Fogg, G. E. (1983). The ecological significance of extracellular products of phytoplankton photosynthesis. Botanica Mar. 26: 3-14

Fuhrman, J. A., Azam, F. (1980). Bacterioplankton secondary production estimates for coastal waters of British Columbia, Antartica and California. Appl. environ. Microbiol. 39: 1085-1095

Fuhrman, J. A., Azam, F. (1982). Thymidine incorporation as a measure of bacterioplankton production in marine surface waters: evaluation and field results. Mar. Biol. 66: 109-120

Gieskes, W. W., Kraay, G. W. (1983). Unknown chlorophyll a derivatives in the North Sea and the tropical Atlantic Ocean revealed by HPLC analysis. Limnol. Oceanogr. 28: $757-766$

Hagström, A., Ammerman, J. W., Henrichs, S., Azam, F. (1984). Bacterioplankton growth in seawater: II. Organic matter utilization during steady-state growth in seawater cultures. Mar. Ecol. Prog. Ser. 18: 41-48

Hammer, K. D., Eberlein, K. (1981). Parallel experiments with Thalassiosira rotula in outdoor plastic tanks; Development of dissolved free amino acids during an algae bloom. Mar. Chem. 10: 533-544

Hammer, K. D., Brockman, U. H. (1983). Rhythmic release of dissolved free amino acids from partly sychronised Thalassiosira rotula under nearly narural conditions. Mar. Biol. 74: 305-312

Hobbie, J. E., Daley, R. J., Jasper, S. (1977). Use of nuclepore filters for counting bacteria by fluorescence microscopy. Appl. environ. Microbiol. 33: 1225-1228

Ittekot, V. (1982). Variations of dissolved organic matter during a plankton bloom: Qualitative aspects, based on sugar and amino acid analyses. Mar. Chem. 11: 143-158

Jensen, L. M. (1983). Phytoplankton release of extracellular organic carbon, molecular weight composition, and bacterial assimilation. Mar. Ecol. Prog. Ser. 11: 39-48

Jørgensen, N. O. G. (1982). Heterotrophic assimilation and occurrence of dissolved free amino acids in a shallow estuary. Mar. Ecol. Prog. Ser. 8: 145-159

Jørgensen, N. O. G., Søndergaard, M., Hansen, H. J., Bosselmann, S., Riemann, B. (1983). Diel variation in concentration, assimilation and respiration of dissolved free amino acids in relation to planktonic primary and secondary production in two eutrophic lakes. Hydrobiologia 107: $107-122$

Keller, M. D., Mague, T. H., Badenhausen, M., Glover, H. E. (1982). Seasonal variations in the production and consumption of amino acids by coastal microplankton. Estuar. coast. Shelf Sci. 15: 301-315

Laane, R. W. P. M. (1983). Seasonal distribution of dissolved and particulate amino acids in the Ems-Dollart estuary Oceanologica Acta 6: 105-109

Lampert, W. (1978). Release of dissolved carbon by grazing zooplankton. Limnol. Oceanogr. 23: 831-834

Lancelot, C. (1979). Gross excretion rates of natural marine phytoplankton and heterotrophic uptake of excreted products in the southern North Sea, as determined by shortterm kinetics. Mar. Ecol. Prog. Ser. 1: 179-186

Lancelot, C. (1983). Factors affecting phytoplankton extracellular release in the southern bight of the North Sea. Mar. Ecol. Prog. Ser. 12: 115-121

Lancelot, C. (1984). Extracellular release of small and large molecules by phytoplankton in the southern bight of the North Sea. Estuar. coast. Shelf Sci. 18: 65-77

Lancelot, C., Billen, G. (1984). Activity of heterotrophic bacteria and its coupling to primary production during the spring phytoplankton bloom in the southern bight of the North Sea. Limnol. Oceanogr. 29: 721-730

Larsson, U., Hagström, $\AA$. (1979). Phytoplankton exudate release as an energy source for the growth of pelagic bacteria. Mar. Biol. 52: 199-206

Larsson, U., Hagström, §.. (1982). Fractionated phytoplankton primary production, exudate release and bacterial production in a Baltic eutrophication gradient. Mar. Biol. 67 $57-70$

Laws, E. A., Bannister, T. T. (1980). Nutrient- and lightlimited growth of Thalassiosira fluviatilis in continuous culture, with implications for phytoplankton growth in the ocean. Limnol. Oceanogr. 25: 457-473

Lindeboom, H. J., Merks, A. G. A. (1983). Annual changes in nutrient, DOC and POC concentrations and their relationship with chemical and biological processes in a closed estuary. Mitt. Geol.-Palaont. Inst. Univ. Hamburg, Sonderband $\mathrm{H}$ 55: 315-329

Lindroth, P., Mopper, K. (1979). High performance liquid chromatographic determination of subpicomole amounts of amino acids by precolumn fluorescence derivatization with O-Phthaldialdehyde. Analyt. Chem. 51: 1667-1674

Lorenzen, C. J. (1966). A method for the continuous measurements of in vivo chlorophyll concentration. Deep Sea Res. 13: $223-227$

Macko, S. A., Green, E. J. (1982). An investigation of the dissolved free amino acids and their relation to phytoplankton cell density in the Damariscotta River estuary, Maine. Estuaries 5: 68-73

Mague, T. H., Friberg, E., Hughes, D. J., Morris, I. (1980). Extracellular release of carbon by marine phytoplankton; a physiological approach. Limnol. Oceanogr. 25: 262-279

Mopper, K., Lindroth, P. (1982). Diel and depth variations in dissolved free amino acids and ammonium in the Baltic Sea determined by shipboard HPLC analysis. Limnol. Oceanogr. 27: 336-347

Moriarty, D. J. W., Pollard, P. C. (1981). DNA synthesis as a measure of bacterial productivity in seagrass sediments. Mar. Ecol. Prog. Ser. 5: 151-156

Moriarty, D. J. W., Pollard, P. C. (1982). Diel variation of bacterial productivity in seagrass (Zostera capricorni) beds measured by the rate of thymidine incorporation into DNA. Mar. Biol. 72: 165-173

Mullin, M. M., Sloan, P. R., Eppley, R. W. (1966). Relationship between carbon content, cell volume, and area in phytoplankton. Limnol. Oceanogr. 11: 307-311

Newell, R. C., Lucas, M. I., Linley, E. A. S. (1981). Rate of degradation and efficiency of conversion of phytoplankton debris by marine microorganisms. Mar. Ecol. Prog. Ser. 6: 123-136

Perry, M. J., Talbot, M. C., Alberte, R. S. (1981). Photoadapta- 
tion in marine phytoplankton: Response of the photosynthetic unit. Mar. Biol. 62: 91-101

Pollard, P. C., Moriarty, D. J. W. (1984). Validity of the tritiated thymidine method for estimating bacterial growth rates: Measurements of isotope dilution during DNA synthesis. Appl, environ. Microbiol. 48: 1076-1083

Poulet, S. A., Martin-Jézéquel, V. (1983). Relationships between dissolved free amino acids, chemical composition and growth of the marine diatom Chaetoceros debile. Mar. Biol.. 77: 93-100

Poulet, S. A., Martin-Jézéquel, V., Head, R. N. (1984). Distribution of dissolved free amino acids in the Ushant front region. Mar. Ecol. Prog. Ser. 18: 49-55

Redalje, D. G. (1983). Phytoplankton carbon biomass and specific growth rates determined with the labeled chlorophyll a technique. Mar. Ecol. Prog. Ser. 11: 217-225

Redalje, D. G., Laws, E. A. (1983). The effects of environmental factors on growth and chemical and biochemical composition of marine diatoms. I. Light and temperature effects. J. exp. mar. Biol. Ecol. 68: 59-79

Riemann, B., Sondergaard, M. (1984). Measurements of diel rates of bacterial secondary production in aquatic environments. Appl. environ. Microbiol. 47: 632-638

Riley, J. P., Segar, D. A. (1970). The seasonal variation of the free and combined dissolved amino acids in the Irish Sea. J. mar. biol. Ass. U. K. 50: 713-720
Sepers, A. B. J. (1981). Diversity of ammonifying bacteria Hydrobiologia 83: 343-350

Sigleo, A. C., Hare, P. E., Helz, G. R. (1983). The amino acid composition of estuarine colloidal material. Estuar. coast. Shelf Sci. 17: 87-96

Steeman-Nielsen, E. (1952). The use of radioactive carbon $\left({ }^{14} \mathrm{C}\right)$ for measuring organic production in the sea. J. Cons. perm. int. Explor. Mer 18: 117-140

Straskrabova, V. (1979). Oxygen methods for measuring the activity of water bacteria. Arch. Hydrobiol. Beih. Ergeb. Limnol. 11: 3-10

Strickland, J. D. H., Parsons, T. R. (1972). A practical handbook of seawater analysis. Fish. Res. Bd Can. Bull. 167: $1-311$

Watson, S. W., Novitsky, T. J., Quinby, H. L., Valois, T. W. (1977). Determination of bacterial number and biomass in the marine environment. Appl. environ. Microbiol. 33: 940-946

Wiebe, W. J., Smith, D. F. (1977). Direct measurement of dissolved organic carbon release by phytoplankton and incorporation by microheterotrophs. Mar. Biol. 42: 213-223

Wolter, K. (1982). Bacterial incorporation of organic substances released by natural phytoplankton populations. Mar. Ecol. Prog. Ser. 7: 287-295 